\title{
E-Musrenbang as a Means in Increasing Community Participation in Development Planning in Indonesia: Its Challenges and Obstacles
}

\author{
Teguh Kurniawan \\ Department of Public Administration Faculty of Administrative Science, Universitas Indonesia, \\ Depok, Indonesia \\ teguh.kurniawan@ui.ac.id
}

\begin{abstract}
The advancement of information and communication technology through the internet has offered a new form of participation and interaction between government and society so that in the end it can push the higher level of understanding and acceptance of society to government action. The condition achieved through the use of various e-government applications. This paper attempts to discuss how e-musrenbang applications implemented by some local governments in Indonesia contribute to increasing community participation in development planning as well as the numerous challenges and obstacles faced in realizing it. To achieve the objectives, this paper uses a qualitative approach with literature studies on some documents and data sources that discuss the implementation of e-musrenbang in Indonesia.
\end{abstract}

Keywords: Community participation; E-musrenbang; Development planning

\section{Introduction}

The internet and all other forms of digital communications have become important instruments in all sectors, including the public sector. The use of the Internet has accelerated the communication process between government and society and can increase public participation in governance.

In the planning process, the use of application of participative techniques based on internet and e-government tools is alleged to increase inclusion of various stakeholders (Scorza, Casas, and Carlucci, 2011). The involvement of various stakeholders is believed to improve the quality of development policies and their implementation.

In the Indonesian context, the use of e-government to increase community involvement in development planning has done through the use of e-musrenbang applications by both central and local government agencies. The effectiveness of community participation in development planning through the use of e-musrenbang by various government agencies is, of course, interesting to learn. Therefore, this paper tries to find out how e-musrenbang can increase community participation in development planning as well as the challenges and obstacles it faces. 


\section{E-musrenbang and community participation}

\section{E-Musrenbang as a Form of E-Government Application in Development Planning in Indonesia}

According to Holmes (2001), e-government is the use of information technology, in particular, the internet, to deliver public services in a much convenient, customer-oriented, costeffective, and altogether different and better way. It affects an agency's dealings with citizens, business, and other public agencies as well as its internal business processes and employees.

Another definition of Bhatnagar (2009), e-government is a term used loosely to describe the legacy of any use of information and communication technology (ICT) within the public sector. For those who see it as some form of an extension of e-commerce to the domain of the government, it represents the use of the Internet to deliver information and services to the government. Furthermore, Bhatnagar (2009) mentioned about e-readiness as the determining factor of success in e-government application. This e-readiness consists of (a) the extent to which computerization of back-end processes has been conducted as well as hardware, software and networking infrastructure required to provide access points to clients at the front-end; (b) a strong intent to reform governance backed up by demonstrated political will and leadership; (c) capacity to design and implement e-government systems as demonstrated by the existence of institutions, which can assist in systems analysis, design, process re-engineering and software development; (d) availability of funds from public, private and multilateral sources to support the e-government effort; (e) existence of an enabling legal framework encompassing privacy and security of data, legal sanction of new forms of storage and archiving, and laws that accept paperless transactions; and (f) finally, the most important factor is the attitude of the civil servants. Civil servants need to have a customer orientation, willingness to change, adequate ICT literacy, and a modicum of honesty and integrity.

Related to the implementation of e-government, then one of the applications used in Indonesia, especially in the process of development planning is e-musrenbang or electronic musrenbang. Musrenbang (musyawarah perencanaan pembangunan or development planning meeting) is a mechanism in the development planning system in Indonesia that designed as an interstakeholder's forum to prepare the National Development Plan and Regional Development Plan. One of the stakeholders involved in the implementation of musrenbang is the community. Community participation in musrenbang is a mandate from the Law on National Development Planning System. Based on the provisions of Law Number 25 theYear 2004 regarding National Development Planning System, musrenbang is a forum among actors to draw up a Regional Development Plan. The Law on National Development Planning System also mandates the optimization of community participation in the development planning process.

The Surabaya City Government first developed e-musrenbang and implemented since 2009. Furthermore, this initiative was developed by the Ministry of National Development Planning/National Development Planning Agency (Kementerian PPN/Bappenas) since 2015.

According to the Surabaya City Government, the development of the city must base on the need of all its people. That is why it is important for the city government to hear the aspirations of its citizens and through e-musrenbang, the delivery of people's aspirations becomes easier and 
more advanced. Meanwhile, e-musrenbang was built by Kementerian PPN/Bappenas to support the planning synergy between central government and local government in the preparation of the government work plan both at the central and regional levels.

\section{Community Participation in Theory}

According to King, Feltey and Susel (1998), public participation or community participation has four main components, namely (a) issues or situations; (b) the structure, system, and administrative process in which participation takes place; (c) administrators; and (d) the community. Another view of community participation is from the opinion of O'Connel (1999) who argues that society should convince of the need to exercise its rights and obligations in a balanced way. In this context, all that has to do is to awaken people's awareness of what they can do for the common good.

In relation to community empowerment, Yang (2005) raised the issue of the need for mutual trust between public administrators and citizens to increase public involvement in the public administration, where trust has four dimensions, namely: (a) trust of citizens to fellow citizens; (b) trust of citizens to the elite; (c) trust of the elites against fellow elites; and (d) trust of the elites to citizens. In addition to the trust that must build between the public administrator and the community and vice versa, there are a number of things that must consider in order to raise public awareness to participate in government activities. The trust is according to Mitchell (2005) related to the need for shared vision and some other attributes to realize an effective partnership between government and society. These attributes are: (a) compatibility among participants based on mutual trust and reward; (b) benefits to all partners; (c) the equality of power with partners; (d) communication channels; (e) adaptability; and (f) the existence of integrity, patience and willingness to solve problems.

Another thing that must consider for making people have a willingness and ability to participate are to solve dilemma problems faced by the community when they are willing to participate. According to Roberts (2004), as quoted in Callahan (2007), there are at least six dilemmas in the effort to involve the community, namely: (a) the dilemma related to the magnitude of the community; (b) the dilemmas associated with marginalized groups of society; (c) riskrelated dilemmas; (d) technological and skill-related dilemmas; (e) time-related dilemmas; and (f) dilemmas related to common good.

\section{Research method}

To be able to achieve the expected objectives, this paper uses a qualitative approach with literature studies on some documents and data sources that discuss the implementation of e-musrenbang in Indonesia. These documents, either in the study reports or data from various government institutions and news from some mass media. The data are then analyzed qualitatively by using the available theoretical framework on e-government and community participation.

By considering the limited time and available data, the focus of the analysis limited to the implementation of e-musrenbang by the Surabaya City Government and the DKI Jakarta Provincial Government. The e-musrenbang by Surabaya City Government choose because it is the pioneer of 
e-musrenbang and this initiative has been awarded innovation of public service from the Ministry of Administrative Reform in 2014. The e-government application of Surabaya City Government can access via http://musrenbang.surabaya.go.id/. The e-musrenbang of the DKI Jakarta Provincial Government chosen because it entered as one of the finalists in shortlisted to the final in the 3rd Guangzhou International Award for Urban Innovation in 2016. The e-government application of DKI Jakarta Provincial Government can access through link http://musrenbang.jakarta.go.id.

In addition to relying on literature studies, researchers also used a number of information obtained from interviews with a number of parties in the Surabaya City Government and the DKI Jakarta Provincial Government. Interviewees in Surabaya City are officials from the Office of Communications and Information while the interviewees in DKI Jakarta Province include officials from the Regional Development Planning Board, smart city units, sub-district (Kelurahan) heads and some community leaders.

\section{Results and discussions}

Based on the data collected, some information on e-musrenbang implementation by Surabaya City Government and DKI Jakarta Provincial Government and its relationship with increasing community participation in development planning and challenges and obstacles encountered described as follows.

\section{E-Musrenbang as a Means of Increasing Community Participation in Development Planning}

Increased public participation from the implementation of e-musrenbang can be seen based on the number of proposals proposed by the community through the e-musrenbang website. Based on information obtained from the e-musrenbang website at the Surabaya City Government and the DKI Jakarta Provincial Government obtained results as can be seen in table 1 below. Because the data on e-musrenbang website of DKI Jakarta Provincial Government only exist for 2016 and 2017, the data shown for Surabaya City Government is also only for the year 2016-2017. In the emusrenbang website of Surabaya City Government can be found data from 2009-2017 although the data of 2014-2015 cannot access at the time of writing this paper.

Table 1. Number of Proposals Submitted

\begin{tabular}{|l|l|l|l|}
\hline \multirow{2}{*}{ No } & \multicolumn{3}{|l|}{ Number of Proposals } \\
\cline { 2 - 4 } & Regions & $\mathbf{2 0 1 6}$ & $\mathbf{2 0 1 7}$ \\
\hline 1 & $\begin{array}{l}\text { Surabaya } \\
\text { City }^{\text {a }}\end{array}$ & 2,580 & 3,316 \\
\hline 2 & $\begin{array}{l}\text { DKI Jakarta } \\
\text { Province }\end{array}$ & 50,213 & 29,480 \\
\hline \multicolumn{4}{|c|}{ a.http://musrenbang.surabaya.go.id } \\
b.http://musrenbang.jakarta.go.id
\end{tabular}


Based on the data in table 1 it can be seen that there is an increasing number of proposals inputted on the e-musrenbang website of Surabaya City Government from 2,580 proposals in 2016 to 3,316 proposals in 2017 . Out of 2,580 proposals in 2016, 1,753 proposals are proposals from community neighborhood (Rukun Warga/RW), and 827 proposals are proposals from the community. While the number of proposals 3,316 proposals in 2017 , as many as 2,831 proposals is a proposal from community neighborhood $(R W)$ and 485 proposals are proposals from the community.

For the condition in Jakarta, based on data in table 1 it can be seen that the number of proposals proposed in 2016 is as much as 50.213 proposals and in 2017 was 29,480 proposals. Of the total number of proposals of 50,213 in 2016, 48,458 proposals are proposals derived from the consultation of citizens at the community neighborhood $(R W)$ level and 1.755 proposals derived from the proposed by the sub-district (Kelurahan) government. While the total number of proposals is 29,480 in 2017, 28,465 proposals are proposals derived from the consultation of citizens at the community neighborhood $(R W)$ level and 1.015 proposals derived from the proposed by the sub-district (Kelurahan) government.

Related to the conditions in Jakarta, based on the results of interviews with some parties can be seen that e-musrenbang began to be developed by the DKI Jakarta Province since 2015 and then continue to be updated up to now. Initially developed in 2015, e-musrenbang applications have not opened up direct community participation but only to facilitate community leaders $(R W$ chairs). Furthermore, in 2017 this newly given direct access to the general public to be able to enter proposals for development activities. There are some improvements in e-musrenbang implementation in 2015, 2016 and 2017. In 2015 a quota system applied where the quota divided by community neighborhood $(R W)$. Each community neighborhood $(R W)$ is given the maximum number of proposals that can be submitted. By 2016, the quota system is not enforced other than the applied menu system in the submission of proposals. This led to the existence of euphoria so that the number of proposals submitted to be abundant. The number of proposals submitted in 2016 is 50,213 proposals of which 48,458 proposals are from community neighborhood $(R W)$. By 2017 , the e-musrenbang system is being improved upon which templates are created from proposals so that proposals will be more standardized both regarding format and budget standards. Also, the general public can also directly participate and can participate throughout the year. Participation in the musrenbang process will be an input for the next year's planning. For participation to be done by the community itself and by the conditions and needs, then the participation is done by using Identification of Identity Number (NIK) as well as location tagging by using geotagging application. As a result of such changes, there was a decrease in the number of proposals in 2017 to as many as 29,480 proposals.

Implementation of e-musrenbang in DKI Jakarta Province is also supported by other application (QLUE application) which is an application that can be used by the public to file complaints and e-budgeting applications. QLUE is an application built to realize Jakarta as Smart City. The results of the QLUE application are also used in determining planning priorities where community grievances will be analyzed and become inputs for development planning by the 
government. Also, starting in 2017 the results of e-musrenbang are also synchronized with ebudgeting. With this synchronization, people can see how their proposed plans have been accommodated in e-budgeting. E-budgeting can only be accessed by the government while the public can only monitor.

Referring to the information contained in table 1, then when viewed based on the data on the number of proposals present in the e-musrenbang website it can see that the implementation of e-musrenbang has not been proven to be related to the increase of public participation. Although in e-musrenbang in Surabaya City has increased, but the number of proposals that directly input by the community has decreased. The number of proposals that have increased is the number of proposals discussed in the process of consultation at community neighborhood level $(R W)$, where although there are communities here but represented by community leaders and not community directly. Meanwhile, in the Jakarta case, the role of e-musrenbang in increasing public participation still needs to be proven considering the direct involvement of the community is possible since 2017 so it needs to be deepened again how the community utilizes the opportunity.

This finding certainly needs to be reconfirmed in a more comprehensive study. It is also necessary to trace information to the relevant agencies managing the existence of e-musrenbang website to be able to re-confirm the amount of data and information obtained and therefore could provide more adequate facts and conditions.

\section{The Challenges and Obstacles in Implementation of E-Musrenbang}

Neither e-government nor community participation is an easy thing to do. There are some challenges and obstacles to be faced in the effort to implement e-government and community participation.

Regarding e-government application, as Bhatnagar puts it, its success will be determined by how far the existing e-readiness is in government and society. Likewise, regarding community participation, where efforts to increase community participation will require serious and extraordinary efforts to be undertaken by the government. This effort is related to how not only provides access to community participation through e-musrenbang but also how to build capabilities that enable communities to participate effectively, including those related to ereadiness as referred to by Bhatnagar. Efforts to increase community participation must be designed and planned clearly and should support the existence of rules that serve as a legal umbrella for community involvement.

In connection with Bhatnagar's opinion, based on search results the main obstacle is related to connectivity and public access to use e-musrenbang applications. In Jakarta, there are still areas that do not have adequate internet connection as in Thousand Islands Regency. Also, many community leaders ( $R W$ chairs) still have knowledge gaps and skills in using computers and the internet. Another obstacle is related to the socialization where there are still many people in Jakarta who do not know about the existence of this e-musrenbang application.

In the case of socialization, the DKI Jakarta Provincial Government only performs socialization on a stratified basis that is only socialized to the Municipality/Regency Government and then the Municipality/Regency Government will socialize to the District and Sub-District. The 
District and Sub-District governments are then expected to socialize with the community, and it does not work well so that many people in Jakarta are not aware of the existence of this application. Meanwhile, related to the capability and capability of the community leader ( $R W$ chairs) in using the application, the DKI Jakarta Province has only once conducted the training to these RW chairs. There is still a need for systematic efforts to help improve the capacity and capabilities of RW chairs in using the application, so there is no need to request assistance to the sub-district officers.

\section{Conclusions}

Based on the discussion, the implementation of e-musrenbang has not assessed for success in increasing community participation in development planning. The application of e-musrenbang in increasing community participation will be determined by e-readiness and the ability to remove the barriers that the community has to participate actively. A more comprehensive study is needed to provide adequate findings and information.

There are some problems encountered in the implementation of e-musrenbang are related to connectivity and access to the internet, the ability of community leaders in using applications, and socialization to the community and other stakeholders. For the implementation of emusrenbang applications that could increase community participation in the development, then the handling and completion of these obstacles need to get attention.

\section{References}

Bhatnagar, S. (2009). Unlocking e-government potential: Concepts, cases, and practical insights. New Delhi: SAGE Publications India.

Callahan, K. (2007) Elements of effective governance: Measurement, accountability, and participation. Boca Raton, FL: CRC Taylor \& Francis Group.

Holmes, D. (2001). E-Gov: E-Business Strategies for Government. Clerkenwell, London: Nicholas Brealey Publishing.

King, C. S., K.M. Feltey, and B.O. Susel. (1998). The question of participation toward authentic public participation in public administration. Public administration review, 58, 317-326.

Mitchell, B. (2005). Participatory partnerships: engaging and empowering to enhance environmental management and quality of life?. Social indicators research, 71, 123-144.

O'Connell, B. (1999). Civil society: The underpinnings of american democracy. Hanover, NH: University Press of New England.

Scorza, F., G.L. Casas, and A. Carlucci. (2011). Onto-planning: innovation for regional development planning within EU convergence framework. In lecture notes in computer science, B. Murgante, O. Gervasi, A. Iglesias, D. Taniar, and B.O. Apduhan, Eds. Berlin Heidelberg: Springer-Verlag, 6783, 243-254.

Yang, K. (2005). Public administrators' trust in citizens: a missing link in citizen involvement efforts. Public Administration Review, 65, 273-285. 